\title{
Restricted expression of anti-type II collagen antibody isotypes in mice suppressed for collagen-induced arthritis
}

\author{
THOMAS F KRESINA ${ }^{12}$ AND CANDACE K FINEGAN \\ From the Departments of ${ }^{\prime}$ Medicine and ${ }^{2}$ Pathology, Case Western Reserve University, School of \\ Medicine, Cleveland, Ohio 44106
}

SUMMARY The present study details the time course and isotype distribution of the immune os response to type II collagen in collagen-induced arthritic mice and mice suppressed for collagen-induced arthritis. The serum of arthritic mice was observed to contain significantly higher $(p<0.005)$ concentrations of antibodies to lype II collagen than that of mice suppressed for $\vec{c}$ arthritis at all times tested. For the arthritic mice anti-type II collagen antibodies ranged from $\stackrel{\Omega}{\Xi}$ $0 \cdot 2 \pm 0 \cdot 2(\mathrm{SD})$ to $6 \cdot 1 \pm 0 \cdot 7 \mathrm{mg} / \mathrm{ml}(\mathrm{g} / \mathrm{l})$. Serum values for mice suppressed for collagen-induced arthritis ranged from $0.05 \pm 0.04$ to $0.6 \pm 0.04 \mathrm{mg} / \mathrm{ml}$. Analysis of the isotypes of these responses showed an expression of anticollagen molecules restricted to the IgG1 subclass in mice suppressed for collagen arthritis throughout the time course $(p<0 \cdot 01)$. The data indicate that mice suppressed for collagen-induced arthritis can mount a primary and secondary immune response to the arthrogenic stimuli. This response, however, is mainly restricted to the $\operatorname{lgG} 1$ subclass of antibodies. This restricted subclass expression of anticollagen antibodies may represent a mechanism of suppression of arthritis in the murine model of collagen-induced $\stackrel{\otimes}{\mathbb{D}}$ arthritis.

A polyarthritis can be induced in specific strains of rats $^{1}$ or mice ${ }^{2}$ by immunisation with native homologous or heterologous type II collagen preparations. These animal models of proliferative synovitis are characterised by the development of both cellular and humoral immune responses to type II collagen. ${ }^{34}$ Collagen-induced arthritis (CIA) can be adoptively transferred to naive rats by sensitised spleen cells ${ }^{5}$ and passively transferred by immunoglobulin $G$ specific for type II collagen. ${ }^{6}$ These observations support the concept that collageninduced arthritis results from immunological hypersensitivity to type II collagen.

Recent studies have noted that the immune responses to collagen and the arthritic responses in rats with collagen-induced arthritis can be modulated by free collagen and anticollagen antiserum. ${ }^{7}$ In addition, administration of collagen coupled spleen cells, ${ }^{\ngtr}$ native type II collagen, ${ }^{9}$ or specific

Accepted for publication 7 June 1985.

Correspondence to Dr Thomas F Kresina, Division of Rheumatology, Department of Medicine. University Hospitals of Cleveland, Cleveland, Ohio 44106. constituent $\mathrm{CNBr}$ peptides ${ }^{10}$ before immunisation with type II collagen results in the antigen specific suppression of collagen-induced arthritis in rats. Rats administered collagen-coupled red blood cells ${ }_{-}^{\circ}$ have also been used as splenic cell donors in studies 3 showing the adoptive transfer of antigen specific suppression of collagen arthritis. " A recent study from this laboratory indicates that $\mathrm{Thy}^{+} \mathrm{Lyl}^{-} 2^{+}$응 type II collagen specific spleen cells ( $T$ cells) are generated in murine lymphatic tissues on in-o travenous preinoculation with native heterologous type II collagen and are efferent suppressor cells. ${ }^{12} \mathrm{~N}$ Furthermore, these $T$ suppressor cells affect chronicN cell-mediated and serum antibody titres to collagenN and concomitant erythema and oedema of synovitis ${ }^{\omega}$ observed in murine collagen-induced arthritis. The present study presents a time course of the humoral

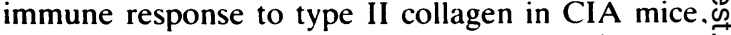
CIA suppressed mice, and type II collagen immune mice. In addition, the isotypes of the antibodyo repertoires were determined. The data indicate that for CIA suppressed mice a reduced and restricted $\overrightarrow{\mathbb{D}}$ expression of serum antibodies to type II collagen is observed. 


\section{Material and methods}

\section{I C E}

DBA/1J six-week-old females were obtained from Jackson Laboratories, Bar Harbor, Maine.

PREPARATION OF NATIVE INTERSTITIAL COLLAGENS

Type I collagen was isolated from pepsin digests of rabbit skin, and type II collagen was isolated from rabbit xiphoid process. The collagens were subsequently purified from the pepsin digest by differential salt precipitation and native state carboxymethylcellulose chromatography. ${ }^{13}$ Under these conditions native interstitial collagen can be totally resolved from basement membranes, other related collagenous components, and proteoglycan moieties. Assessment of purity was performed by molecular sieve, ion exchange chromatography and $5 \%$ sodium dodecyl sulphate polyacryamide gel electrophoresis. In addition, type II collagen preparations at concentrations of $>2 \mathrm{~g} / \mathrm{l}$ were routinely assayed for uronic acid content. No uronic acid, i.e., proteoglycan moieties, was detected, with the limits of detection at $1 \mu \mathrm{g}$ uronic acid.

\section{RADIOIMMUNOASSAY FOR ANTICOLLAGEN}

A NTI BO D I ES

Serum anticollagen antibodies were quantified by solid phase radioimmunoassay. ${ }^{14}$ In brief, polyvinyl microtitre plates were incubated with $20 \mu \mathrm{l}$ of a neutral $\mathrm{pH}$ sodium bicarbonate solution containing the type II collagen $(1 \mathrm{~g} / \mathrm{l})$ for $24 \mathrm{~h}$ at $4^{\circ} \mathrm{C}$. After adherence of antigen to the wells the plates were washed with a bicarbonate buffer $\mathrm{pH} 7.5$ and filled with a solution of $2 \%$ bovine serum albumin in bicarbonate for $24 \mathrm{~h}$ at $4^{\circ} \mathrm{C}$. This procedure reduced the non-specific background binding by blocking the remaining sites of adherence in the wells. After this incubation $20 \mu \mathrm{l}$ of bicarbonate buffer and $20 \mu \mathrm{l}$ of serum (dilution 1:10, 1:50, 1:100, 1:1000, 1:10 000) were incubated in the wells for $18 \mathrm{~h}$ at $4^{\circ} \mathrm{C}$. The wells were washed thoroughly with bicarbonate buffer and filled with $50 \mu \mathrm{l}(125 \mathrm{ng})$ of ${ }^{125}$ I-labelled affinity purified goat antimouse IgG, Fc fragment specific (Cooper Biochemical, Malvern, Pennsylvania). ${ }^{15}$ This reagent was incubated in the wells of the plates for $12 \mathrm{~h}$ at $4^{\circ} \mathrm{C}$. The wells were washed 12 times with bicarbonate buffer, dried by air, and counted in a Beckman 5500 gammacounter. Quantification of the bound antibody was determined by means of the binding data derived from samples containing known quantities of specifically purified anti-type II collagen antibodies. Anti-type II collagen antibodies were isolated by elution from type II collagen coupled Sepharose 4B ( $\mathrm{CNBr}$ method) with a solution of $0 \cdot 1 \mathrm{M}$ glycine-HC1 $\mathrm{pH} 2 \cdot 5 .^{16}$ Antibody concentration was calculated by determination of the optical density of the solution at $280 \mathrm{~nm}$ and comparison with the molecular extinction coefficient for immunoglobulin molecules, which has a value of 14830 . For isotype determination serum dilutions for analysis were adjusted to similar non-saturating concentrations of antibody and incubated as previously described in the antigen coated wells for $12 \mathrm{~h}$ at $4^{\circ} \mathrm{C}$. After the incubation the wells were washed with bicarbonate buffer and filled with $50 \mu \mathrm{l}(125 \mathrm{ng})$ of one of the following: ${ }^{125}$ I-labelled affinity purified goat antimouse IgM, antimouse IgG1, antimouse IgG2a, antimouse IgG2b, antimouse IgG3 (Southern Biotech Associates, Birmingham, Alabama). These affinity purified antibody preparations were also individually cross absorbed against all other mouse antibody isotypes and against human Cohn fraction II globulin to reduce non-specific binding activity. The specific radioactivity of the labelled anti-isotype reagents ranged from 2100 to 2400 $\mathrm{cpm} / \mathrm{ng}$, and the radiolabel was $96-98 \%$ trichloroacetic acid precipitable in all cases. Values at individual points were obtained in triplicate, and the data were expressed as the percentage of cpm bound by labelled ligand of the total cpm bound for the five isotypes analysed. This assay, therefore, assumes an equal average binding affinity to substrates of each of the antisubclass polyclonal antisera.

\section{COLLAGEN-INDUCED ARTHRITIS}

Murine collagen-induced arthritis was induced by a modified method of Courtenay et al. ${ }^{2}$ In brief, 100 $\mu \mathrm{g}$ of purified rabbit type II collagen emulsified in complete Freund's adjuvant was injected intradermally at the base of the tail on day 0 . A second identical injection of antigen emulsified in complete Freund's adjuvant (CFA) was administered intraperitoneally on day 14 . Mice were observed for onset of arthritis which, in general, occurred four weeks after the initial injection. Animals were monitored daily for arthritis until they were killed. Preinoculation of antigen for suppression studies occurred three days before day 0 . A single intravenous injection of $500 \mu \mathrm{g}$ of native collagen (type I or type II) in $\mathbf{0 . 2} \mathrm{ml}$ of isotonic saline was administered. Immune animals were given two intraperitoneal injections of type II collagen/CFA at day 0 and day 14 .

PATHOLOGY SCORING

Paws were read blindly and individually scored for arthritis on a scale of 1-5 based on the amount of erythema and enlargement, gross distortion of normal anatomical features, or limitation of movement of the joints. ${ }^{12}$ Scores ranged from 1 corres- 
ponding to mild erythema of the foot pad to 5 corresponding to ankylosed and deformed joints with diffuse oedema. In addition, the number of enlarged terminal digits on inflamed paws was recorded. Destructive articular disease was subsequently confirmed by radiological analysis. The pathology scores presently tabulated are the chronic arthritic values obtained at death of the mice, 50 days after the initial immunisation with type II collagen/CFA.

\section{STATISTICS}

p Values for antibody concentrations and isotype determinations were obtained by the Student's $t$ test. $p$ Values for the pathology scoring were obtained by a Mann-Whitney rank sum test. Analysis of variance was performed with a Texas Instruments 59 applied statistics library package.

\section{Results}

GROSS PATHOLOGY

The data in Table 1 summarise the arthritis pathology score for CIA mice (groups 1 and 2), CIA suppressed mice (group 3 ), and type II collagen

Table 1 Arthritis gross pathology score*

\begin{tabular}{|c|c|c|c|c|c|c|c|}
\hline \multirow[t]{3}{*}{ Group } & \multirow{3}{*}{$\begin{array}{l}\text { Inoculation } \\
\text { before } \\
\text { injection }\end{array}$} & \multirow{3}{*}{$\begin{array}{l}\text { Incidence } \\
\text { of } \\
\text { inflam- } \\
\text { mationt }\end{array}$} & \multicolumn{5}{|c|}{ Inflammation $\neq$} \\
\hline & & & \multicolumn{2}{|c|}{$\begin{array}{l}\text { Hind } \\
\text { paw }\end{array}$} & \multicolumn{2}{|c|}{$\begin{array}{l}\text { Fore } \\
\text { paw }\end{array}$} & \multirow{2}{*}{$\begin{array}{l}\text { Terminal } \\
\text { digits } \\
\text { involved }\end{array}$} \\
\hline & & & $L$ & $R$ & $L$ & $R$ & \\
\hline 1 & Saline & $13 / 13$ & $2 \cdot 0$ & $1 \cdot 5$ & 0.9 & $1 \cdot 1$ & $1 \cdot 0$ \\
\hline 2 & $\begin{array}{l}500 \mu \mathrm{g} \\
\text { native type } \\
\text { I collagen }\end{array}$ & $8 / 8$ & $2 \cdot 5$ & $2 \cdot 0$ & $1 \cdot 3$ & $1 \cdot 5$ & $1 \cdot 3$ \\
\hline 3 & $\begin{array}{l}500 \mu \mathrm{g} \\
\text { native type } \\
\text { II collagen }\end{array}$ & $1 / 9$ & 0.5 & $0 \cdot 1$ & 0.2 & $0 \cdot 1$ & 0.0 \\
\hline 4 & None\| & $6 / 15$ & $1 \cdot 1$ & 0.5 & 0.5 & $0 \cdot 5$ & 0.5 \\
\hline
\end{tabular}

${ }^{*}$ Animal paws individually scored for arthritis on a scale of $0-5$ based on the amount of erythema and oedema, distortion or ankylosis of the joint.

†Number of animals with a recorded pathology score $>1$ by day 50 divided by the total number of mice per group at day 50 . ¥Average pathology score for the individual paw of each mouse in the designated group. A statistical analysis of the inflammation pathology scores showed no statistical difference (NS) for values obtained for group $1 v 2$ and for group $3 v 4$. However, comparison of group $1 v 3$, group $2 v 3$, and $1 v 4$ showed a statistically significant value for inflammation at the following levels. Group $1 v 3$ : hind paw $L-p<0.002 ; \quad R-p<0.0006$; fore paw $L-p=N S$; $\mathrm{R}-\mathrm{p}=0.05$. Group $2 v 3$ : hind paw $\mathrm{L}-\mathrm{p}=0.0006 ; \mathrm{R}-\mathrm{p}<0.006$; fore paw $L-p=0.0005 ; R-p=0.008$. Group $1 v 4$ : hind paw $L-p=0.005 ; R-p=0.007$; fore paw $L-p=N S ; R-p=0.06$.

$\$$ Average number of enlarged terminal digits per inflamed (score $\geqslant 1$ ) paw.

|Mice were immunised intraperitoneally with $100 \mu \mathrm{g}$ type II collagen emulsified in complete Freund's adjuvant on day 0 and day 14 . immune mice (group 4). Groups 1 and 2 (saline and $\stackrel{\text { ? }}{\text {. }}$ type I collagen preinoculated, respectively) had $a \overrightarrow{\vec{F}}$ high incidence of arthritis. As indicated by the gross pathology scores, inflammation (erythema and oede-ma) was most prominent in the hind paws, with the left paw, on average, more severely affected than $\overrightarrow{\widetilde{\Phi}}$ the right. The corollary was observed for the fore paws with the right paw displaying more severes gross pathology, on average, than the left paw. For $\overrightarrow{0}$ all inflamed paws at least one terminal digit was $\overrightarrow{-}$ involved.

The gross pathology scores and inflammationo incidence for group 3 (native type II collagen? preinoculated) were substantially reduced. p Valuescr listed in Table 1 ranged from 0.05 to 0.0005 . Eight of nine animals in this group displayed either nos pathology or only mild erythema on the left fore oro hind paws, with no swelling of the terminal digits.Only one animal in this group had enlargement, ${ }_{\infty}$ distortion, or limitation of movement of the joints.?

The type II collagen immune animals (group 4$)^{\mathfrak{m}}$ showed a relatively low $(40 \%)$ incidence of inflammation. The gross pathology inflammation $\infty$ scores ranged from 0 to 3 , indicating that only? moderate inflammation was observed, if at all. In fact the gross pathology scores determined for groups 4 were not statistically significant in comparison with the values obtained for the CIA suppressed group. These data indicate that, in general, type II collagen immune mice display, as a group, the gross pathol $\overrightarrow{\vec{A}}$ ogy of non-arthritic animals.

IMMUNE RESPONSE TO TYPE II COLLAGEN帝 The variation with time of the concentration of serum antibody to native type II collagen in CIA CIA suppressed, and immune animals is shown iniTable 2. This table shows antibody concentrations.for the primary immune response to native type IB collagen (day 10) and time points for the secondary immune response (days 20, 30, 40, 50). As shown ing Table 2 CIA mice (saline and type I collagen preinoculated) had a quantitatively similar serum? antibody concentration throughout the time course For the saline preinoculated group serum $\mathrm{IgC}^{\circ}$ antibody values to type II collagen ranged from $0.4 \pm 0.6$ (SD) $\mathrm{g} / \mathrm{l}$ on day 10 to $5 \cdot 6 \pm 1.1 \mathrm{~g} / \mathrm{l}$ on day 50 స్ while the type I collagen preinoculated group ranged from $0 \cdot 2 \pm 0 \cdot 2 \mathrm{~g} / \mathrm{l}$ on day 20 to $6 \cdot 1 \pm 0 \cdot 7 \mathrm{~g} / \mathrm{b}$ on day 50. In comparison, CIA suppressed mice्⿱ (group 3) displayed significantly reduced $(\mathrm{p}<0.005)$ ? concentrations of serum antibody to native type Ifo collagen for all the time points tested. The serump anti-type II collagen antibody concentrations obtained for these animals ranged from $0.05 \pm 0.040$ $\mathrm{g} / \mathrm{l}$ on day 20 to $0.6 \pm 0.04 \mathrm{~g} / \mathrm{l}$ on day 50 . These datas taken together indicate that CIA mice have higher 
Table 2 Time course of serum anticollagen $\operatorname{IgG}$ molecules*

\begin{tabular}{|c|c|c|c|c|c|c|}
\hline \multirow[t]{2}{*}{ Group } & \multirow{2}{*}{$\begin{array}{l}\text { Inoculation before } \\
\text { injectiont }\end{array}$} & \multicolumn{5}{|c|}{ No of days after initial immunisation } \\
\hline & & 10 & 20 & 30 & 40 & 50 \\
\hline 1 & Saline & $0.4 \pm 0.6 \ddagger$ & $0.7 \pm 0.7$ & $1 \cdot 9 \pm 1 \cdot 2$ & $1 \cdot 4 \pm 1 \cdot 2$ & $5 \cdot 6 \pm 1 \cdot 1$ \\
\hline 2 & Type I collagen & $0.5 \pm 0 \cdot 9$ & $0 \cdot 2 \pm 0 \cdot 2$ & $1 \cdot 5 \pm 0.9$ & $1 \cdot 0 \pm 0 \cdot 9$ & $6 \cdot 1 \pm 0 \cdot 7$ \\
\hline 3 & Type II collagen & $0.09 \pm 0.05$ & $0.05 \pm 0.04$ & $0.5 \pm 0.4$ & $0 \cdot 3 \pm 0 \cdot 1$ & $0.6 \pm 0.04$ \\
\hline 4 & None & $0.09 \pm 0.07$ & $0 \cdot 7 \pm 1 \cdot 1$ & $1 \cdot 9 \pm 1 \cdot 7$ & $1 \cdot 4 \pm 1 \cdot 3$ & $1 \cdot 2 \pm 1 \cdot 4$ \\
\hline
\end{tabular}

*Anticollagen antibodies measured by solid phase radioimmunoassay as described in the text.

+Groups 1-3: preinoculated mice were administered saline or native neutral salt soluble collagen preparations intravenously before immunisation (day 0-intradermal; day 14 IP) with native type II collagen. Group 4: immune mice were given $100 \mu \mathrm{g}$ native type II collagen (2x) IP at day 0 and day 14 .

$\ddagger$ Values are mean $\pm \mathrm{SD}(\mathrm{g} / \mathrm{l})$. Antibody concentrations were determined individually in triplicate from 13 animals in group 1 , eight animals in group 2, nine animals in group 3, and 15 animals in group 4 . The bound antibody was quantified by means of the binding data derived from samples containing known quantities of specifically purified anti-type II collagen antibodies.

serum concentrations of antibodies to native type II collagen than do CIA suppressed mice as the course of arthritis progresses. On the other hand, mice suppressed for collagen-induced arthritis are capable of mounting primary and secondary immune responses, albeit diminished, to the arthrogenic stimuli.

Serum anti-type II collagen antibody concentrations from CIA mice (groups 1 and 2) and CIA suppressed mice (group 3 ) can be compared with values obtained for type II collagen immune mice (Table 2, group 4). It can be seen that serum concentrations of anti-type II collagen antibody in the primary immune response of immune mice do not differ quantitatively from the values for CIA suppressed mice. However, this value is significantly lower $(p<0.005)$ than the primary immune response values of CIA (groups I and II, Table 3). The secondary immune response of type II collagen immune mice closely paralleled the CIA mice response on days 20,30 , and 40 . The values were substantially higher than the serum IgG concentration of anti-type II collagen antibodies in CIA suppressed mice (group 3).

Further studies were performed which identified the isotypes of the serum antibodies directed to native type II collagen in the various groups. The data detailing the subclass distribution of the immune response for days 10,20 , and 30 are presented in Fig. 1. The two groups of mice presented are the CIA mice, type I collagen preinoculated (representative of the values obtained for both groups of CIA mice), and CIA suppressed mice (type II collagen preinoculated). As shown in Fig. 1 the primary immune response of the eight CIA mice (day 10) to type II collagen comprises a majority of IgM molecules (a mean value of $57 \%$ ). An im- munoglobulin isotype switch was observed in this group for the secondary immune response (days 20 and 30), with an increased expression of IgG molecules, particularly IgG1, IgG2a, and IgG2b isotypes. However, an analysis of serum anti-type II collagen antibodies in CIA suppressed mice showed that the expression of isotypes of anti-type II

Table 3 Time course of IgGI anti-type II collagen antibodies*

\begin{tabular}{|c|c|c|c|c|c|c|}
\hline \multirow{3}{*}{ Animal } & \multicolumn{6}{|c|}{ No of days after initial immunisation } \\
\hline & \multicolumn{2}{|c|}{$\begin{array}{l}10 \\
\text { Group } t\end{array}$} & \multicolumn{2}{|l|}{$\begin{array}{l}20 \\
\text { Group }\end{array}$} & \multicolumn{2}{|l|}{$\begin{array}{l}30 \\
\text { Group }\end{array}$} \\
\hline & $I$ & II & $I$ & II & $I$ & II \\
\hline $\begin{array}{l}1 \\
2 \\
3 \\
4 \\
5 \\
6 \\
7 \\
8 \\
9\end{array}$ & $\begin{array}{r}0 \\
16 \\
67 \\
1 \\
0 \\
0 \\
29 \\
16 \\
D \S\end{array}$ & $\begin{array}{l}86 \\
69 \\
84 \\
67 \\
60 \\
70 \\
86 \\
\text { ND } \\
87\end{array}$ & $\begin{array}{l}20 \\
15 \\
71 \\
98 \\
73 \\
D \\
66 \\
41 \\
D\end{array}$ & $\begin{array}{l}88 \\
91 \\
92 \\
82 \\
82 \\
83 \\
88 \\
\text { ND } \\
93\end{array}$ & $\begin{array}{l}25 \\
54 \\
92 \\
47 \\
32 \\
\mathrm{D} \\
52 \\
33 \\
\mathrm{D}\end{array}$ & $\begin{array}{l}68 \\
70 \\
68 \\
78 \\
84 \\
59 \\
82 \\
\text { ND } \\
80\end{array}$ \\
\hline $\begin{array}{l}\overline{\mathbf{x}} \pm \text { SEM } \\
\mathrm{p} \|\end{array}$ & $\begin{array}{r}16 \pm 23 \\
<\end{array}$ & $\begin{array}{l}74 \pm 11 \\
.001\end{array}$ & $55 \pm 30$ & $\begin{array}{l}87 \pm 4 \\
0 \cdot 01\end{array}$ & $48 \pm 22$ & $\begin{array}{l}73 \pm 9 \\
0.01\end{array}$ \\
\hline
\end{tabular}

*Antibodies measured by solid phase radioimmunoassay as described in the text. Data presented as percentage cpm bound by labelled ligand of the total cpm of all isotypes tested (IgM, IgG1, IgG2a, IgG2b, IgG3).

tGroup I: (CIA) type I collagen preinoculated and subsequently immunised with type II collagen/CFA; group II: (CIA suppressed) type II collagen preinoculated and subsequently immunised with type II collagen/CFA.

$\ddagger N D=$ not determined for animals that did not display anti-type II collagen antibodies.

$\S \mathrm{D}=$ deceased.

Ilp Values obtained by Student's $t$ test. 
PERCENT TOTAL RESPONSE

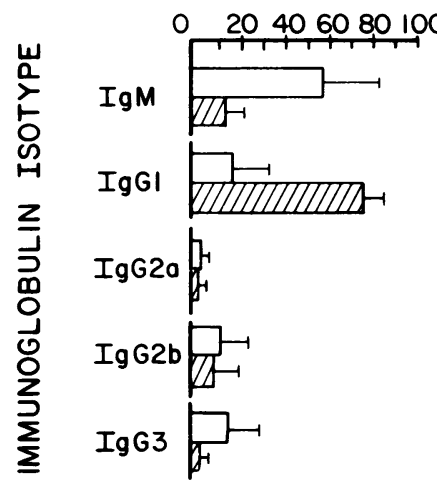

DAY 10

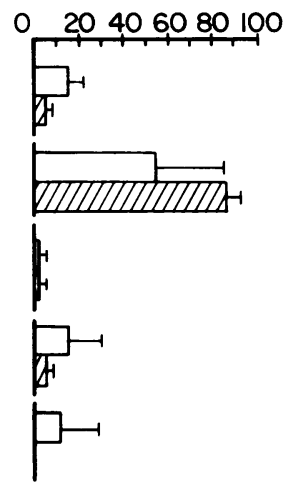

DAY 20

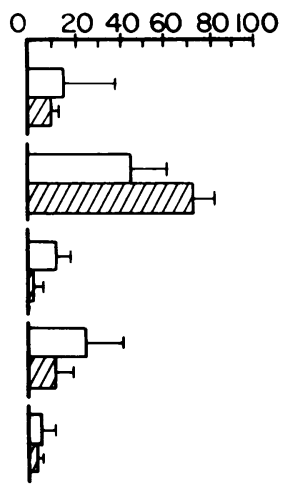

DAY 30

Fig. 1 Diagrammatic representation of the immunoglobulin isotype distribution for antibodies directed to native type II collagen in CIA mice ( $\square$, native type I collagen preinoculated) and CIA suppressed mice (D, native type II collagen preinoculated). Data presented for the native type I collagen preinoculated CIA group are representative of the saline preinoculated CIA group. Data are presented as mean \pm SEM of the eight CIA mice and eight CIA suppressed mice. (One CIA suppressed mouse did not express serum antibodies to native type II collagen.) The diminished primary IgM response (day 10) for the CIA suppressed group and the comparatively augmented IgG1 secondary immune response (days 20 and 30) are statistically significant $(p<0.01)$. The augmented primary IgG1 response (day 10) of the CIA suppressed mice is statistically significant $(p<0.001)$ by Student's $\mathrm{t}$ test. Analysis of the variance between CIA suppressed mice and the saline and type I collagen preinoculated groups (CIA mice) showed the following probability of variance: day 10, IgM p=0.001; day 10, IgG1 $p=0.00005$; day 20, IgG1 $p=0.002$; day 30, IgG1 $p=0.0001$.

collagen antibodies was more restricted. In the primary immune response (day 10 ) six of the nine CIA suppressed mice had less than $11 \%$ of their total anti-type II antibodies expressed as IgM molecules. The remaining three mice had anti-type II collagen IgM molecules as 13,27 , and $28 \%$ of the total antibodies. The predominant isotype expressed as the primary anti-type II collagen immune response of CIA suppressed mice was the IgG1 molecule $(74 \pm 11 \%$, day 10$)$. Table 3 shows that the IgG1 subclass was predominantly expressed throughout the time course in CIA suppressed mice group II ( $\overline{\mathrm{x}} \pm$ SEM: day $2087 \pm 4 \%$; day 30 $73 \pm 9 \%$; day 50 (data not shown) $70 \pm 14 \%$ ). This restriction of expression of IgG1 molecules specific for the arthrogenic stimuli is significant $(\mathrm{p}<0.01)$ throughout the time course.

Type II immune mice showing a $40 \%$ incidence of inflammatory polyarthritis can be divided into an arthritic group (six animals) and a non-arthritic group (nine animals). Analysis of the anticollagen antibody subclass distribution in these animals showed a similar though less striking expression of IgG1 antibodies in the non-arthritic group. For the primary and secondary immune responses of the arthritic mice the percentage IgM and IgG1 anticollagen molecules of the total response for each time point was as follows: day 10 , IgM $27 \pm 16(\overline{\mathrm{x}} \pm$ SEM),

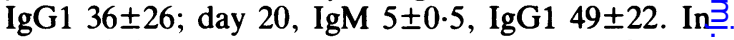
the arthritic mice a smaller percentage of IgM anticollagen molecules in the primary immune response was observed, with a concomitant increaseo in IgG1 expression for both time points. The values obtained for these animals were: day $10, \operatorname{IgM} 11 \pm 8 ;$

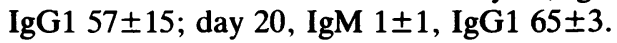

\section{Discussion}

The present study details the time course of the immune response to type II collagen in CIA mice CIA suppressed mice, and type II collagen immune mice. In addition, the immune response to type IIS collagen is dissected with regard to the isotypes of the anti-type II collagen molecules. The presento data taken together indicate that mice suppressed for collagen-induced arthritis with regard to gross. pathology (erythema and oedema) are capable of generating a humoral immune response to the 
arthrogen, native type II collagen. This immune response, however, is significantly suppressed in comparison with the serum anti-type II collagen antibody concentrations observed in CIA mice. In addition, the isotype distribution of the immune response to type II collagen is significantly different in the arthritic and CIA suppressed mice. In the CIA suppressed mice the anticollagen repertoire throughout the time course almost exclusively comprised molecules of the IgG1 subclass. The predominance of IgG1 anticollagen molecules expressed in mice suppressed for CIA suggests that a restriction in the subclass expression of anticollagen molecules may be a mechanism in the suppression of arthritis in the murine model of arthritis.

A recently reported study of the IgG subclasses expressed in arthritic and non-arthritic rats showed statistically significant differences in the expression of IgG1, IgG2a, IgG2b, and total IgG. ${ }^{17}$ The data in this study, which analysed a single time point 21 days postimmunization with type II collagen, noted a significantly reduced expression of serum IgG molecules in non-arthritic rats, with particularly raised levels of IgG2a molecules in the arthritic rats. ${ }^{17}$ The IgG antibody subclass of rats has differing biological properties compared with the murine IgG subclass and therefore cannot be directly compared. However, this study did note observations similar to those of Firth et al. ${ }^{17}$ i.e., a decreased serum anticollagen IgG concentration in CIA (non-arthritic) suppressed mice and an increased expression of IgG2a and IgG2b isotypes in the secondary immune response to type II collagen in CIA mice.

The molecular mechanism of the selective suppression of anticollagen antibody in CIA suppressed mice could be related to the recent observation from this laboratory of type II collagen-specific T suppressor cells in mice suppressed for collageninduced arthritis. ${ }^{12}$ In this regard, previous studies with the dinitrophenyl (DNP) hapten have shown that DNP-specific $T$ cells induced by preinoculation with hapten-coupled mycobacterium selectively inhibit IgE antibody isotype responses. ${ }^{18} \mathrm{~A}$ more recent study has characterised a $\mathrm{T}$ suppressor cell which specifically limits the expression of IgG2a and IgG2b but not IgG1 anti-DNP plaque forming antibodies. ${ }^{19}$ In addition, a $T$ cell hybrid has recently been described which produces high levels of immunoglobulin binding factors specific for the IgG1 and IgG2 subclasses. ${ }^{20}$ These factor(s) specifically inhibit the secretion of the corresponding subclass of antibody from B cells. These studies indicate that the recently described collagen specific suppressor $T$ cells observed in CIA suppressed mice $^{12}$ could regulate the isotype expression of anticollagen antibodies through the secretion of specific isotype binding lymphokines. Such lymphokines could be relevant to the immunotherapeutic suppression of arthritis through the suppression of anticollagen antibodies. To this point, numerous studies have suggested either an anticollagen antibody specific mediation of the pathogenesis of collagen arthritis or a role for antibody responses to collagen in the induction of collagen-induced arthritis. ${ }^{3} 6816$

It is of interest to note the increased concentration of anti-type II collagen antibodies in the chronic phase (day 50) of the CIA animals. The values show a four- to sixfold increase over the day $\mathbf{4 0}$ serum concentrations. A previous study showing a nonquantitative time course of the humoral immune response in murine collagen-induced arthritis did not observe a raised serum anticollagen antibody concentration in chronic arthritis. ${ }^{3}$ An antibody increase late in the secondary immune response could result from the release of additional antigenic molecules derived from the breakdown of connective tissue observed in chronic erosive arthritis. Data to support this hypothesis are obtained by an analysis of the anticollagen antibody isotypes for these animals at these time points. The data reveal an average increase of $14 \%$ in IgM production at day 50. Such an increase would indicate that previously resting B cell clones were being stimulated to produce additional anticollagen molecules.

Finally, it is of interest to note that the predominate expression of anticollagen antibodies of the IgG1 subclass in CIA suppressed mice may represent the expression of non-pathological antibodies. Analysis of the functional characteristics of murine immunoglobulins has shown that IgG1 antibodies are not effective in activating the complement cascade. Previous studies have implied that complement may be involved in the breakdown of cartilaginous structures in animal models of arthritis. ${ }^{21} 22$ Thus a restricted expression of such antibodies in the CIA suppressed mice would allow for a humoral immune response to the arthrogenic stimuli without involving a complement mediated breakdown of cartilaginous structures. A recent study with affinity purified rabbit anticollagen IgG molecules has reported such an observation. ${ }^{23}$ Rabbit anticollagen IgG molecules when passively transferred to recipient rats failed to transfer arthritis and activate complement but were observed to bind the surface of articular cartilage.

The authors acknowledge the helpful discussions with Dr Gary Kammer and the excellent secretarial assistance of Mrs Terri Grenwis-Woodcraft. This work was supported by NIH grant AM-20618 and the Revco D S Foundation. 


\section{References}

1 Trentham D E, Townes A S, Kang A H. Autoimmunity to type II collagen: an experimental model of arthritis. J Exp Med 1977: 146: $857-68$.

2 Courtenay J S, Dallman M J, Dayad A D, Martin A, Mosedale B. Immunization against heterologous type II collagen-induced arthritis in mice. Nature $1980 ; 283: 666-8$.

3 Stuart J M. Townes A S, Kang A H. Nature and specificity of the immune response to collagen in type II collagen-induced arthritis in mice. $J$ Clin Invest 1982; 69: 673-83.

4 Trentham D E, Townes A S, Kang A H. Humoral and cellular sensitivity to collagen in type II collagen-induced arthritis in rats. J Clin Invest 1978; 61: 89-96.

5 Trentham D E, Dynesius R A. David J R. Passive transfer by cells of type II collagen-induced arthritis in rats. J Clin Invest 1978; 61: 359-66.

6 Stuart J M, Cremer M A. Townes A S, Kang A H. Type II collagen-induced arthritis in rats. Passive transfer with serum and evidence that $\mathrm{IgG}$ anti-collagen antibodies can cause arthritis. J Exp Med 1982; 155: 1-16.

7 Staines N A, Hardingham T, Smith M. Henderson B. Collageninduced arthritis in the rat: modification of immune and arthritic responses by free collagen and immune anti-collagen antiserum. Immunology 1981; 44: 737-44.

8 Schoen R T, Greene M I, Trentham D E. Antigen specific suppression of type II collagen-induced arthritis by collagencoupled spleen cells. J Immunol 1982; 128: 717-9.

9 Cremer M A. Hernandez A D, Townes A S, Stuart J M, Kang A H. Collagen-induced arthritis in rats: antigen specific suppression of arthritis and immunity by intravenously injected native type II collagen. J Immunol 1983; 131: 2995-3000

10 Englert M E, Landes M J. Oronsky A L. Kerwar S S. Suppression of type II collagen-induced arthritis by the intravenous administration of type II collagen or its constituent peptide $\alpha 1$ (II) CB10. Cell Immunol 1984: 87: 357-65.

11 Brahn E, Trentham D E. Antigen-specific suppression of collagen arthritis by adoptive transfer of spleen cells. Clin Immunol Immunopathol 1984: 31: 124-31.

12 Kresina T F. Moskowitz R W. Adoptive transfer of suppression of arthritis in the murine model of collagen induced arthritis: evidence for a type II collagen specific suppressor T cell. J Clin Invest 1985; 75: 1990-8.
13 Kresina T F, Rosner I A. Goldberg V M. Moskowitz R W. Immunoglobulin G-induced experimental chronic immune $\vec{F}$ synovitis: cell mediated immunity to native interstitial collagen $\stackrel{\vec{D}}{\mathcal{O}}$ molecules and their constituent polypeptide chains. Cell $\mathrm{Im}$ munol 1984: 87: 504-16.

14 Kresina T F, Rosner I A. Goldberg V M, Moskowitz R W. Fine specificity of serum anti-collagen molecules in experimental immune synovitis. Ann Rheum Dis 1985; 44: 328-35.

15 McConalley $\mathrm{P}$ J. Dixon F J. A method of trace iodination of proteins for immunologic studies. Int Arch Allergy A $\rho p l$ क Immunol 1966; 29: 185-96.

16 Stuart J M. Tomada K. Yoo T J. Towes A. Kang A H. Serum transfer of collagen induced arthritis. II. Identification and $\vec{\omega}$ localization of autoantibody to type II collagen in donor and $\mathrm{O}$ recipient rats. Arthritis Rheum 1983: 26: 1237-44.

17 Firth S A, Morgan K, Evans H B. Holt P J L. IgG subclasses in collagen-induced arthritis in the rat. Immunol Lett 1984: 7: of 243-7.

18 Kishimoto T, Hirai Y, Suemura M, Yamamura Y. Regulation $\vec{\sigma}$ of antibody responses in different immunoglobulin classes. I. O Selective suppression of anti-DNP IgE antibody response by 음 preadministration of DNP-coupled mycobacterium. J Immunol 1976; 117: 396-404.

19 Lowy I, Joskowicz M. Theze J. Characterization of suppressor cells regulating in vitro expression of $\mathrm{IgG} 2 \mathrm{a}$ and $\mathrm{IgG} 2 \mathrm{~b}$ antibody responses. J Immunol 1982; 128: 768-73.

20 Lowy I. Brezan C. Neauport-Sauties C. Theze J. Friedman W H. Isotype regulation of antibody production: T-cell hybrids can be selectively induced to produce $\operatorname{lgG} 1$ and $\operatorname{lgG} 2$ subclassspecific suppressor immunoglobulin-binding factors. Proc Natl Acad Sci USA 1983: 80: 2323-7.

21 Kerwar S S. Bauman N. Oronsky A L. Sloboda A E. Studies on type II collagen-induced polyarthritis in rats. Effect of complement depletion. J Immunopharmacol 1982: 3: 323-37.

22 Morgan K. Claque R B. Shaw M J. Firth S A. Twose T M. Lennox-Holt P J. Native type II collagen-induced arthritis in the rat. The effect of complement depletion by cobra venom factor. Arthritis Rheum 1981; 24: 1356-62.

23 Ridge SC. McReynolds R A. Mitcho Y C. Bauman N. Oronsky A L. Kerwar S S. Passive transfer of collagen arthritis: studies with affinity-purified anti-collagen $\mathrm{IgG}$ prepared in rabbits. Clin Immunol Immunopathol 1984: 33: 4(12-11. 